opc/en/classified-compilation/20001938/index.html (дата звернення: 11.07.2020).

5. Чечерський B.I. Використання кріоконсервованих гамет та ембріонів як гарантія реалізації права людини на репродуктивне відтворення. Юридичний науковий електронний журнал. 2019. № 4. C. 34-37.

6. Thomas V. Life after death: regulating posthumous reproduction. April 17, 2019. URL: https://www.howtoregulate.org/posthumousreproduction-2/\#sdendnote1sym (дата звернення: 03.08.2020).

7. Pennings G. Belgian Law on Medically Assisted Reproduction of Supernumerary Embryos and Gametes. European Journal of Health Law. 2007. № 14. P. 257.

8. Assisted Human Reproduction Act: Закон Канади від 29.03.2004. URL: https://laws-lois.justice.gc.ca/eng/acts/a-13.4/ (дата звернення: 03.08.2020).

9. Assisted Reproductive Technology Act: Закон Нового Південного Уельсу (Австралія) від 2007 p. URL: https://www.legislation.nsw.gov.au/ \#/view/act/2007/69/full (дата звернення: 11.07.2020).

10. Simana S. Creating life after death: should posthumous reproduction be legally permissible without the deceased's prior consent? Journal of Law and the Biosciences. 2018. № 5 (2). P. 329-354. URL: https://www.ncbi.nlm.nih.gov/pmc/articles/PMC6121062/ (дата звернення: 01.08.2020).

DOI https://doi.org/10.30525/978-9934-588-92-1-15

\title{
ПРАВОВЕ РЕГУЛЮВАННЯ ОРГАНІЗАЦІЇ ТА ДІЯЛЬНОСТІ КОЛЕКТИВІВ БЕЗРОБІТНИХ В УСРР В ПЕРІОД НОВОЇ ЕКОНОМІЧНОЇ ПОЛІТИКИ (1921-1929 РР.)
}

\section{Харасик Н. О.}

асистент кафедри історії держави і права Украӥни та зарубіжних краӥн

Національного юридичного університету імені Ярослава Мудрого м. Харків, Україна

Із запровадженням нової економічної політики у 1921 р. та, як наслідок, появою вільного ринку праці неминуче призвело до стрімкого 
зростання кількості безробітних. Партійним керівництвом держави було прийнято рішення про відновлення бірж праці, на які покладались посередницькі функції з працевлаштування, реєстрація безробітних, направлення їх на роботу за заявками роботодавців, надання допомоги у зв'язку із безробіттям.

Допомога безробітним могла бути грошовою, натуральною та трудовою. До трудової допомоги належали: створення колективів безробітних, артілей, організація курсів для перекваліфікації та перенавчання безробітних, які мали спеціальності, що не користувалися попитом на ринку праці, а також організація громадських робіт.

Велика увага приділялася адаптації безробітних на підприємстві. При біржах створювалися експертні комісії для визначення професії та кваліфікації робітників та службовців, які були звільнені у зв'язку із скороченням штатів рівня їхньої реальної кваліфікації шляхом проведення експертизи, практичного випробування на виробництві. Вони давали відповідні рекомендації та консультації усім, хто звертався до них. Якщо вакансії, які були, не зовсім відповідали професії та рівню кваліфікації, бажаючих отримати роботу направляли на спеціальні курси, де проводилася професійна підготовка $[1,54]$.

Основним видом трудової допомоги була організація колективів безробітних, які сприяли тимчасовій зайнятості. Колективи створювалися $з$ числа безробітних, які були зареєстровані на біржі праці, та в залежності від характеру праці поділялися на виробничі, торговельні та трудові.

Склад колективів був непостійним. Змінність складу була покликана необхідністю надання трудової допомоги якомога більшій кількості безробітних. Тому термін перебування безробітного у колективі був обмеженим - у виробничих колективах - шість місяців, у трудових i торговельних - три місяці. Припускалася наявність у колективах постійного складу з числа кваліфікованих працівників, які замінювалися іншими безробітними лише у випадку їхнього переходу на постійну роботу. Основний постійний склад не повинен був перевищувати 20 відсотків від загальної кількості зайнятих у колективі безробітних. У трудових колективах принцип змінності дотримувався більш суворо, і створення постійного складу не дозволялося.

Правовий статус колективів визначався Тимчасовим положенням, затвердженим постановою ВУЦВК та РНК УСРР від 23 травня 1925 року [2]. Згідно цього положення окремі колективи та їх об'єднання діяли на підставі статутів, які реєструвалися Комітетами бірж праці. Прибуток окремого колективу розподілявся таким чином: 25 відсотків надходило на розгортання діяльності того ж самого колективу, 10 відсотків відраховувалося на користь об'єднання 70 
колективів, якщо даний колектив входив до об'єднання, решта коштів надходила до Комітету біржі праці на розширення трудової допомоги безробітним. Підприємства і колективи, які утворювалися при одній біржі праці складали об'єднання, на чолі якого було правління або одноосібний управляючий.

Учасники колективу на весь час роботи у ньому залишались на обліку біржі праці і не втрачали своєї черги.

Трудові і виробничі колективи безробітних звільнялися від усіх податків і зборів протягом шести місяців від дня утворення, у тому числі і від внесків на соціальне страхування, хоча усі види соціального страхування для членів колективу зберігались. Усі установи при біржі праці - гуртожитки, їдальні, ясла, які обслуговували лише безробітних, зареєстрованих на біржі праці, звільнялися від внесків на соціальне страхування і від сплати комунальних послуг. Після закінчення пільгового періоду до колективів застосовувалось оподаткування кустарно-промислової кооперації. Колективи не могли конкурувати 3 державними та кооперативними підприємствами, оскільки мали на меті лише допомогу безробітним, не здатним отримати роботу. Саме тому ці колективи мали пільги.

Розмір заробітної плати працюючих у колективах безробітних визначався тарифною угодою, яка укладалась між правлінням об'єднання та тією профспілкою, до якої належала певна категорія безробітних. Розмір винагороди визначався у залежності від наявності коштів. В середньому заробітна плата у виробничих i трудових колективах в становила 35-50 крб. на місяць, і відповідала заробітку некваліфікованого робітника. Відпустки надавалися у розмірі двох тижнів особам, які відпрацювали не менше 11,5 місяців. Неповнолітнім відпустка надавалась через 11 місяців роботи терміном на один місяць. У разі неможливості надання відпустки, компенсація видавалась на загальних підставах.

Позитивним моментом було те, що колективи безробітних у низці випадків відновлювали недіючі підприємства. Колективи, що зміцніли, із кількістю працівників 20 осіб, які відпрацювали звітний рік бездефіцитно, передавалися господарським органам і включалися до числа підприємств місцевої промисловості. Безробітні в цьому випадку отримували статус постійних працівників і знімалися з обліку біржі праці. Принцип змінності складу працюючих у цьому випадку на даному підприємстві скасовувався.

Висновки. Із введенням вільного ринку праці радянська держава не мала можливості подолати зростаюче безробіття. Проте тимчасова зайнятість безробітних була дуже необхідним та корисним заходом, що 
надавало можливість безробітним не втратити кваліфікацію, та забезпечувало хоча б невеличку матеріальну підтримку.

\title{
Література:
}

1. О проверке, экспертизе и практическом испытании профессиональной подготовки ищущих труда: Инструкция Наркомтруда СССР № 28. Известия НКТ УССР. 1923. № 3/27. С. 53-56.

2. Тимчасове положення про колективи безробітних від 23 травня 1925 p. ЗУ УСРР. 1925. № 27. Ст. 217.

DOI https://doi.org/10.30525/978-9934-588-92-1-16

\section{ОСОБЛИВОСТІ СТАНОВЛЕННЯ ЗАКОНОДАВСТВА ЗА ДОБИ ЗАХІДНО-УКРАЇНСЬКОЇ НАРОДНОЇ РЕСПУБЛІКИ У НАУКОВОМУ ДОРОБКУ М. ЧУБАТОГО ТА М. ЛОЗИНСЬКОГО}

\author{
Чубата М. В. \\ кандидат юридичних наук, \\ доиент кафедри теорії та історії права та держави \\ Інституту права
}

Київського національного університету імені Тараса Шевченка м. Київ, Украӥна

Законодавчим та державотворчим процесам в ЗУНР одним з перших серед дослідників-правознавців присвятив серію своїх публікацій Микола Чубатий $[1 ; 2 ; 3]$. Як високий урядовець і активний учасник визвольних змагань в ЗУНР, М. Чубатий мав нагоду наочно спостерігати за розбудовою та стабілізацією державного ладу. Особливий інтерес викликає п'ятий підрозділ його книги, названий «Законодавча влада» [2, с. 1-15]. Оцінюючи процеси державного будівництва в ЗУНР, автор наголошував: «Треба собі признати, що на загал велике діло державного будівництва сповнили ми надсподівано успішно» [2, с. 4]. На жаль, у цій праці дослідник не виокремлює конституційне законодавство як самостійний аспект. Дещо пізніше М. Чубатий продовжив дослідження цієї проблематики в грунтовній статті [3, с. 3-12], в якій виокремлює два підрозділи, що стосувалися безпосередньо законодавства ЗУНР: «Історично-правні основи Західньо-Української Республіки» та «Історично-правні основи акту 